\title{
Union Leadership Development as Driver of Equity and Inclusion
}

\author{
Sally Alvarez, Ph.D. \\ Worker Institute, School of Industrial and Labor Relations, \\ Cornell University, \\ New York, New York \\ Jose F. Alvarez, MSOD \\ Alvarez Porter Group \\ New York, New York
}

January 2018

This article in final form was published in the journal Work and Occupations as part of a special issue on an international comparison of efforts to develop young leaders in the labor movement. It is available at https://journals.sagepub.com/doi/10.1177/0730888418786337 


\begin{abstract}
Analysis generated for the research project on Young Workers and the Labor Movement highlighted the need for innovative leadership development if young workers are to be integrated into an increasingly diverse workers' movement, and unleashed to provide leadership in established institutions that face a radically changing economy and workforce. We examine one successful leadership development program: the New York State AFL-CIO/Cornell Union Leadership Institute. We look at the theoretical underpinnings, development, and outcomes of this multi-union, multi-sector program over the past 17 years, note its impact on the New York regional labor movement, and analyze the key factors accounting for the program's successful development of innovative-minded young labor leaders. Those factors venturing beyond the traditional "skill-building " approach of most labor leadership training toward a more transformational model of leadership development; an emphasis on experiential learning, using a variety of learning modes; providing a safe space and what Kurt Lewin describes as "a community of practice" where difficult challenges can be tackled collectively; and using leadership development as a tool to build inclusion and solidarity across many dimensions of difference, including age, race, gender, ethnicity, sector, able-ness, education level, industry, and more.
\end{abstract}




\section{INTRODUCTION}

Involving younger leaders and activists in existing labor institutions is without question one key to the reinvigoration of the labor movement in any country. As economies, technologies, and cultures change, so does the workforce. Labor unions have traditionally lagged behind in responding to those changes. If younger workers bypass unions as relevant forces to ensure decent treatment, labor rights, or civic participation, not only will hard-won rights achieved through past struggles erode, but the future for younger workers in an increasingly deregulated, individualistic and precarious global economy will be less secure. While many approaches to mobilizing and engaging young workers in unions and other forms of collective workplace activism have been tried, illustrated by the cases examined in this volume, success has been uneven.

The research question we explore here is threefold. 1. Can leadership development be an effective intervention in increasing the diversity and inclusiveness of the activist core of a labor organization along dimensions of age, gender, race and ethnicity? 2. If so, what type of leadership development intervention strengthens the effectiveness of the organization, and how? 3. How should these "leadership development" programs and activities be structured to maximize their transformational impact along these dimensions of inclusion, both for individuals and for organizations?

This article uses one union leadership development program to explore the challenges of identifying, and developing leaders in what is fundamentally a complex and contradictory enterprise. A.J. Muste in 1928, argued that labor organizations must simultaneously be both armies and town halls: they must fulfill the dual purposes of 
strategically leading troops (members, allies) in pitched battles against powerful foes (employers, political opponents), and at the same time operate as open, transparent, democratic institutions where often the only common ground among their troops is the employer or the trade. Labor unions are part of the civic fabric of any democracy; yet unions are unique in being required to simultaneously play such contradictory roles. Leaders must juggle the roles of authoritative decision-maker and resolute defender of democratic process. There is nothing in the way that union leaders are generally recruited or formally trained that prepares them for these contradictory demands.

The decline of unions across the industrialized West has weakened democracy and accompanied the rise of a particularly noxious (racist, xenophobic) brand of nationalism. The traditional leaders of unions have not been able to address these trends adequately, and in some instances have been complicit in their rise. The emergence of a populist alt-right in America, and the strength of a truly disturbing neo-fascist movement in Europe testify to the failure of many American labor unions to provide the kind of analysis, vision, and leadership that a moment like this requires. Involving young people in unions is a matter of survival, not just for the labor movements in question, but for the democratic experiment itself. We hope the insights here generate deeper understanding of the unique nature of these leadership roles, and suggest how to help foster a new and diverse generation of leaders.

U.S. workers and their unions face a crisis characterized, by exploding inequality, ${ }^{1}$ by shrinking union membership numbers, by a struggle to reestablish

\footnotetext{
${ }^{1}$ A number of economists have traced the explosive growth of inequality, and many have linked it to the decline in bargaining power of unions. The most renowned is probably Thomas Picketty's Capital in the Twenty-First Century (2013). Les Leopold's work is
} 
workers' right to organize and collectively bargain, and by a pressing need to redefine what unionization means in a $21^{\text {st }}$ century economy. Growing inequality, and the overall decline in union density and power has continued despite a number of victories and innovations, and despite the fact that a number of major American unions have pioneered new strategies and are increasing in membership [e.g. Service Employees (SEIU), Teamsters (IBT), Laborers (LIUNA), the International Alliance of Stage and Theatrical Employees (IATSE)].

This case study spans 19 years of effort: two years of planning (1999-2001), and 17 years of the Institute's operation (2001-2018). Here we trace the four stage of evolution of the program in both structure and content over that time. The faculty conducted formal evaluations of the program in 2007 and 2012, consisting of demographic analysis, surveys of graduates, and follow-up interviews with participants and sponsors. We were interested in defining and assessing the Institute's effectiveness in creating networks among leaders and encouraging the attainment of higher levels of leadership. We were also particularly interested in studying examples of organizing or political outcomes that had resulted from either the Institute curriculum itself, or from the connections the Institute has made possible among the diverse organizations and individuals touched by the program. Data from those formal evaluations inform this paper.

Although we were not solely focused at the beginning (in 1999) on the particular challenges of attracting and developing younger leaders; we were explicitly focused on

important in linking inequality to workers' collective voice: Runaway Inequality: An Activist's Guide to Economic Justice (2015) 
developing a new generation of leaders, and that involved multiple dimensions of diversity, including age. Young people in the U.S. commonly view unions as artifacts of the past: tradition-bound, rigid, unresponsive, bureaucratic, with vestiges of exclusion based on race, gender, age and craft. Jonathan Timm, in The Atlantic analyzed organizing drives at two well-known U.S. companies, Peet's Coffee and Gawker. He argues that millennials struggle for information about unions, have a broader social vision than most unions care about, and are suspicious of the top-down hierarchy they encounter from organizers (Timm 2015). With a decline in the number of young workers from families where parents or grandparents are union members, and as the workforce is relentlessly restructured into informal, entrepreneurial, and precarious work arrangements, young people frequently voice the belief that unions are irrelevant to their work lives. These are not easy things for leaders of traditional unions to hear, and any effort to create a program that would both support their genuine efforts to change their organizations, and also be responsive to young activists is doubly difficult.

At the same time that they dismiss unions, young workers express commitment to social values and political beliefs that unions have fought for historically. Cornell University researchers studied young worker attitudes in 2009 and found that young workers are potential allies, members and leaders of unions, but unions have an uneven record in commitment to young workers (Fontes and Margolies 2010). Additional research on attitudes among young workers in Canada echoes these findings (Gomez, et al 2002). The introductory article in this volume points out the polarity between efforts to involve younger workers that emphasize socialization into the current organizational structures and culture of a union, and efforts that empower young workers to change the union in ways that address more 
current challenges and serve their own interests better. This has emerged as a foundational insight in our work to create a truly impactful program.

The original question we posed to stakeholders in 1999 was "What do unions need to be stronger and more effective?" The answer from the union leaders in our planning group was "better leaders." The second question was "How do we meet that need?" The answer was to envision and design a process/program to train emerging leaders to be better leaders. But better leaders for what kind of union? Are we developing leaders to operate in the same manner, with the same skills and frameworks as current leaders, only more efficiently? Our planners were clear that the workforce was changing, the economy was changing, and unions were not adapting to significantly changed circumstances. They could see that leadership in unions reflected a serious lack of diversity in age, gender, ethnicity, sexual orientation.

\section{The New York State AFL-CIO/Cornell Union Leadership Institute}

The Institute was launched in 2001 as a two-year, multi-union, multi-sector statewide certificate program jointly sponsored by the New York State AFL-CIO, the national AFL-CIO, and Cornell University’s School of Industrial and Labor Relations (ILR). The planning process took two years and involved conversations with numerous labor leaders in the New York area. Over time, the Institute has evolved into its current form: it is now a one-year program that combines classroom seminars, fieldwork, and mentoring, with an option to earn 12 units of undergraduate college credit. The curriculum consists of eight units over that one-year period (two weeklong retreats, four seminars that occur over 3-day weekends, and two fieldwork projects). Three optional electives can be chosen from the non-credit public programming offered by Cornell 
during the one-year program and for one year after graduation. A cohort of 28-34

participants starts each July and graduates the following July.

Currently in its $17^{\text {th }}$ year, the Institute has graduated over 400 labor leaders and leaders of worker-based community organizations in the states of New York, New Jersey, Delaware, Pennsylvania, Massachusetts and Connecticut. Graduation rate is $96 \%$.

Participant must be nominated by a sponsoring organization, and must have held significant positions of leadership in their organizations for a minimum of two years (i.e., elected or appointed officers or staff). Cost at this writing is $\$ 8400$ per participant, with financial aid available. Starting in 2010, the cohort included anywhere from one to five leaders from alternative worker organizations such as worker centers or immigrant rights organizations, a point discussed later.

The Institute is run by the faculty of the Worker Institute at Cornell, with an advisory committee of leaders from sponsoring organizations that meets once a year to make decisions about major policy changes and plan recruitment for the next cohort.

\section{Early Stages of the Institute}

A major driver of the development of the Institute was the AFL-CIO, on both national and state levels. ${ }^{2}$ In 2012, Denis Hughes, past president of the NYS AFL-CIO, reflected on his thinking at the time when this program was first proposed:

By the late 1990s, the decline in the percentage of workers who belonged to unions was already a looming obstacle. We needed more leaders who understood its implications and were capable

\footnotetext{
${ }^{2}$ At the time, Joe Alvarez was the Northeast Regional Director for the AFL-CIO, and Sally Alvarez was on the Extension faculty in the School of Industrial and Labor Relations at Cornell University.
} 
of responding effectively. But too many labor leaders didn't see

the membership decline as a common problem of the labor

movement...It became clear to me that union leaders in our

state did not understand each other's problems and did not

know one another. We needed a teaching mechanism for the

people elected to positions of responsibility in unions, a place to

develop a new breed of solidarity and awareness and learning

so that a technician in a public hospital who is, say, a member

of PEF or DC 37[major public sector unions in NY state-ed],

can relate as a union member to the union plumber he or she is

attending with. ${ }^{3}$

In preparation for the launch of the Leadership Institute in 2001, we reviewed other business, government, and non-profit leadership programs. Labor education for leaders in the U.S. has traditionally focused on labor relations skills and practices, labor law, collective bargaining and contract administration. We found that education specifically focused on leadership effectiveness was rare. While the body of academic and theoretical work on leadership was extensive, research on union leadership was rare, focused mostly on shop steward level leaders. The few studies dealt with individual leadership styles as they related to member motivation or loyalty, rather than effectiveness in leading or changing organizations, especially in a dramatically changing environment (Eisenscher 1998; Hammer 1993; Barling 1992; Barling et al 1995).

\footnotetext{
3 The authors are especially indebted to our colleague and Institute co-director Gene Carroll, as his thorough survey and interview-based evaluation of the program in 2012 has enriched the analysis here. Quotes throughout this paper are drawn from his capstone project for the Master's degree in Labor Studies at the City University of New York. "Developing Labor Leadership: Assessing a Journey to Solid Ground."
} 
In 1993, Indiana-based labor educator Ruth Needleman studied the earlier efforts of SEIU to tackle the issues of racial and gender equity in leadership. She identified two important interventions: the creation of independent spaces for marginalized groups inside these organizations, and the provision of opportunities for these groups to get training and exercise their leadership potential (Needleman 1993). The Leadership Institute was a deliberate effort to provide an opportunity for multi-union, multi-sector, diverse communities to form and learn across their differences.

A set of well-articulated principles guided our decisions about the initial format and approach of the program.

1. Recruitment could be a strategy to help diversify the ranks of union leadership by encouraging sponsorship of individuals earlier in their union careers and more representative of the demographics of their membership: women, people of color, immigrants, etc., who have been traditionally shut out of leadership positions in the labor movement.

2. The value of a learning community. The Institute would be a cohort program that would occur over a series of sessions rather than short "trainings." Participants would create a learning community that would provide opportunities to learn from and challenge each other over time. They would be able to apply concepts and skills back in their home organizations and then return to the next session and debrief with this community.

3. The multi-union nature of the Institute will foster exchange between organizations, with the intention of creating a diverse network that, over time, even after graduation from the program, would increase the level of collaboration within the larger movement.

4. Recruitment of internal candidates, not self-selection, could generate conversations with current leaders about succession. Cornell offers a number of labor education programs that are self-nominated. If a program is all selfnominated, it requires no real engagement with the current leadership of an 
organization. In the Institute, participants are sponsored by their leadership rather than self-selected, to help ensure that they won't be isolated by their organizations when they returned with new ideas and approaches, and to ensure the organization's commitment to the program.

5. Acceptance in the Institute would be selective. This enabled us to prioritize creating a diverse cohort balanced in age, gender, ethnicity, trade and eventually, organization. This was a difficult principle to uphold, given budgetary constraints, and the need for serious conversations with sponsors about sending people who have an appropriate level of experience and influence.

6. The curriculum would focus on strategic thinking and broader issues rather than skills. It would offer understanding about the larger political, social and economic context for workers and unions, but be rooted in participants' practical experience as leaders.

7. The pedagogy would be intensely interactive, with peer learning, multiple learning modalities, and self-assessment as key components.

One major challenge for the program was recruiting those at a level of significant leadership responsibility in the union. We wanted participants who could truly influence the direction of their unions. The NY State AFL-CIO and the regional staff of the AFLCIO played a huge role here, as they had the relationships and stature to approach the potential sponsors to the program. Every leader of a union of significant size in New York State was approached to engage in a conversation about leadership and succession, about their own leadership journeys, their challenges, and their hopes for the future before we asked them to nominate a leader for the program. We encountered some predictable responses: "Why would I train someone who might run against me?" "We do our own training, why should we expose our people to other unions that might instill bad practices?" 
Contradictory realities made recruiting a diverse, and younger, group of participants daunting: To recruit younger leaders, or women, or people of color, or immigrant workers, if they are rarely in positions of leadership, but they required sponsorship by their current leaders, do they even exist?

Thankfully, we also encountered several visionary union leaders who appreciated the opportunity to reflect on an issue they rarely had the leisure to consider. A few saw the potential of engaging and training this new generation in a multi-union context. Some of these leaders actually nominated themselves. Some became stalwart supporters and since 2001 have sent an entire new generation of leaders through it. Graduates from those unions serve now as sponsors for the next generation of leaders.

\section{Curriculum Development and the Evolution of our Theory of Change ${ }^{4}$}

The founders of the Institute articulated a purpose and set of outcomes that guided the creation of the program. While many of those assumptions still hold, over the past seventeen years, the program's theory of change has moved from an early skills-based/ competency model to a situational/contingency model, to its current form, which we call a systems/change-based model. ${ }^{5}$ Our pedagogical approach has been increasingly

\footnotetext{
${ }^{4}$ The concept theory of change is widely used in non-profit and educational settings to describe and test the assumptions behind an educational or organizing program that has the intention of creating change in a certain institution, group, or community. For a concise explanation, see http://www.betterevaluation.org/en/resources/guide/theory_of change.

${ }^{5}$ A description of the evolution of the program is available in a paper by Sally Alvarez presented at the Labor and Employment Relations Conference, New Orleans, Louisiana, January 2008. "Learning to Lead Change: Using Change Theory to Develop Union Leaders." Available from the author.
} 
influenced by experiential learning theory, based on early work by John Dewey, Kurt Lewin and developed by David A. Kolb ${ }^{6}$. Lewin's concept of a community of practice ${ }^{7}$ has been significant for us, where controversial and difficult challenges can be tackled collectively. At the same time, we have introduced significant elements to the curriculum that were not present at the Institute's inception: e.g., formal self-assessment, social and emotional intelligence, social movement theory, and equity and inclusion. These will be discussed later.

In the first two years of the program, we operated on a competency-based model, sometimes termed a deficit model, because it assumes a deficit of skills, which, if filled, will lead to effective leadership. At the opening of the program each year we facilitated a discussion in which participants brainstormed an "ideal labor leader." We used interlocking circles designated as skills, knowledge and qualities a leader needed to possess in order to be effective. These competencies collectively represented the ideal union leader and functioned as the framework for the early curriculum.

This competency-based approach resulted in a series of trainings on particular skills and conceptual bodies of knowledge, such as conflict resolution, labor economics, supervisory skills, etc. Our self-assessment tool had each participant identify his or her

\footnotetext{
${ }^{6}$ See Kolb, D. A. (1984). Experiential learning: Experience as the source of learning and development. Englewood Cliffs, NJ: Prentice-Hall.

${ }^{7}$ Analysis of the concept of "communities of practice" has generally focused on business and academic entities. We found it a transformative concept for labor organizations, where leaders often work in isolation from each other, and sectoral or jurisdictional disputes make collaboration unlikely. For a concise general description of the concept, see Cultivating Communities of Practice. Etienne Wenger, Richard McDermott, William Snyder, Harvard Business School Press. Boston, 2002.
} 
own level of competency in a particular area, and then track through the program whether that skill or competency had been improved. We used experiential learning and interactive pedagogy, but these were still driven by the idea that skills were intrinsic to the individual, and once mastered, could be used in any situation in a way that would de facto represent effective leadership. We were dealing with skills as individual factors (e.g., you are skilled at conflict resolution or not; at listening or not) divorced from the particular organizational or personal challenges faced by the leader.

By the third year, while the program was successful and the curriculum was well received, the approach was clearly too simplistic and limited in its impact on either the participants or their unions. Looking back, we were clearly "training" leaders to be better versions of the current leaders of the labor movement. We were limited by a theory of change and a pedagogical approach that was transactional ${ }^{8}$, limited to skill-building in a generic context. We weren't "developing" a new generation of leaders, and we were not really addressing the need for change in the movement, except by offering a critique of labor's failure to organize enough new members to increase union density.

In spite of participants being sponsored by their organizations, they were still often marginalized in their organizations once they had finished the program. The truly powerful aspect of the program was the space we had created for leaders from across the movement to sit together and actually have opportunities to learn about each other and share strategies. But we felt that the potential to transform how these leaders saw

\footnotetext{
${ }^{8}$ See Paul Clark's Building More Effective Unions (2014) for a discussion of the difference between transactional and transformational leadership models in labor unions.
} 
themselves and their roles in their organizations was limited by the skills-based model we were using.

During this period, faculty were studying Paolo Friere's theories of popular education, and his critique of the banking model of education, in which students are passive receptacles of knowledge and take little responsibility for their own learning (Freire 1970). We revised the curriculum and articulated a different model to try to strengthen the contextual and interactive aspects. We continued to use this new model, which we can see now was a situational or contingency-based model of leadership, for the next four years. This meant more focus on understanding the participants' organizational contexts, including assessing the strengths and weaknesses of their own organizations. We tried to assess wherever the participants were in their organizations and in their leadership practices. We devised a detailed organizational assessment they each conducted in their home institutions after the first seminar. We tightened the requirements for a leadership fieldwork project that had to impact their home organization, and implemented curriculum on navigating political barriers to drive a change process in their unions.

The improvement this model had over the previous model was in its recognition that leadership is not simply a set of skills, but something that happens in context; leadership is more than a title or even a competency, but a set of practices involving others in a complex, multi-faceted environment. We developed a definition of leadership that we still use: Leadership is bringing people together to make something valuable happen that would not happen otherwise. 
We did not actually begin to use the concept of theory of change until 2006. ${ }^{9}$ At that time, we realized we had originally created a program based on a particular theory of change, and we had shifted to a new theory and a new model based on it in 2003. Our earliest theory of change was:

TOC I (2001): If we can define the ideal labor leader, isolate the key competencies (skills), and develop a curriculum focused on those competencies, we will succeed in training an effective group of leaders. A critical mass of leaders with these competencies will change the labor movement.

Dissatisfied with the skills model, we had shifted to a second model of leadership in 2003, which had led to our changing our leadership curriculum to a more situational approach. This new approach was based on the following theory of change: TOC II (2003): Introduce the concept of leadership in different situations and at different levels. Teach the competencies and give the participants opportunities to practice them to help them understand how the competencies can be exercised in different ways at different times. Once they understand the situational nature of leadership, and develop competencies to respond to various situations and challenges, they can change their unions and the labor movement.

In 2007, after seven years of successful operation and growth, the Institute was clearly emerging as a successful intervention in building a network of leaders across New

\footnotetext{
${ }^{9}$ Fleshing out a "theory of change" was a fairly new enterprise in labor education in 2007, though the process has been used extensively in other institutions and sectors, especially in the non-profit service sector. The question of "what are the outcomes of this educational effort?" seemed like a worthy and transformative question to ask. Perhaps the low priority many union leaders place on education could be overcome if outcomes were clearer, and the process could help us retool our programs so they are more likely to achieve the impact we would like to see.
} 
York who collaborated and continued to stay in touch and work together long after graduation. But during the years we had been running the Institute, the AFL-CIO was splitting (2005) into two federations, the immigrant rights movement was on the rise, alternative labor organizations were emerging, and income inequality was surging. While we explicitly discussed emerging events and issues in the Institute curriculum, we also felt we were not helping leaders grapple sufficiently with these larger systemic issues. We also felt we were not addressing the need to actually transform how these leaders were thinking about their work and their work lives. Participants still voiced the frustration that when they returned home with new ideas, they faced the same institutional inertia they left. Our efforts to involve the sponsors in supporting the development of their participants were uneven. We were still in search of a better theory of change and a more transformative curriculum.

At the time, we were also studying experiential learning theory, developed by Alice and David Kolb at Case Western University. ELT seemed to offer a theory- and research-based understanding of what we wanted to achieve, and a direction that we had been moving toward intuitively. We wanted to help leaders transform themselves, and then help to transform their organizations. ELT is built on six propositions (Kolb and Kolb 2005), all of which resonated strongly with our intents and purposes in the Leadership Institute:

1. Learning is best conceived of as a process, not in terms of outcomes. John Dewey calls it a "continuing reconstruction of experience."

2. All learning is relearning, drawing out a student's beliefs and ideas so they can be examined and integrated with new ones. 
3. Learning requires the resolution of conflicts between dialectically opposed modes of adaptation to the world. Differences drive the learning process.

4. Learning is a holistic process of adaptation to the world, involving thinking, feeling, perceiving, and behaving.

5. Learning results from the synergistic transactions between the person and the environment, assimilating new experiences into existing concepts.

6. Learning is the process of creating knowledge in the learner, who learns through experience, not through the passive acceptance of preexisting knowledge.

In 2007 we conducted a thoroughgoing evaluation of the impact of the program. This discussion of impact led to a series of tough questions, the first one being "What exactly are we measuring and how?" It was at this point that we realized we had originally been operating on a particular theory of change (TOC I) that had shifted in 2003 (TOC II) and that was still inadequate; we needed to shift again.

While we had always incorporated an analysis of the need for change in the labor movement into the curriculum, we began to incorporate more elements of organizational change theory, and leadership research on social and emotional intelligence. We began to explore more challenging tools for self-assessment and practical engagement with their home unions. Our theory of change was moving toward helping leaders see themselves as agents of change, rather than as more skilled and effective practitioners of the status quo. This new theory of change can be stated as:

TOC III (2008) Leadership is about transformational change, on both personal and organizational levels. If a leader is going to change their organization, they must first be willing to change themselves. Give participants the opportunity to 
develop personal mastery, develop a vision, and examine the gap between the vision and the current state. If they can understand their environment, be resolutely open to learning, design a process of change, understand themselves and their capacity to be an agent of change, they can change their organizations and the labor movement in order to make their unions relevant to the whole working class"

This model of leadership draws heavily from systems theory, in which the union is comparable to an organic system in a living environment, with the need for leaders who understand their external and internal environment, are skilled at building and managing teamwork through ongoing feedback, are able to respond to the outside environment, build internal capacity, and understand strategic leverage. ${ }^{10}$ This third theory of change resulted in some curricular changes that remain in the program, especially around self-mastery, self-awareness, and emotional and social intelligence. Appendix B is a document from this period in which we articulated the six core principles we felt represented the shift to this new orientation.

As we have gained confidence in what the Institute is accomplishing, we have begun to push more forcefully around changing behaviors and habits, helping participants think through their individual value systems, solving ethical dilemmas, dealing with equity and inclusion in interpersonal as well as organizational ways, building networks, managing conflict, forging and running teams.

Union leadership is an extremely demanding life choice. Labor frequently loses its best people to burnout, broken marriages and relationships, the loss of ethical

${ }^{10}$ These concepts come from the model developed by David Weil of M.I.T. of strategic choice for unions, which we use throughout the Institute curriculum. 
bearings, inability to resolve internal conflict. This has been particularly damaging to efforts to involve more women in leadership, as well as younger people whose expectations of work-life balance is changing. Research conducted by Cornell in 2009 about women in unions involved focus groups of young women union organizers. They reported significant burnout, which they attributed to the abusive conditions, inflexible expectations, and unwillingness of senior leaders (mostly male, but also female) to be responsive to their personal needs and health. They cited issues such as long out of town assignments without breaks, and other family-unfriendly policies that compromised their willingness to continue working for unions, and damaged the relationships between members, potential members, and organizers, who were seen as leading lives that no workers would choose for themselves (Alvarez et al 2009). If we are serious about helping transform the labor movement, and we believe that leadership is a crucial instrument in that process, we felt we had to address these issues.

In 2008 we started using a more in-depth approach to self- assessment and building self-awareness. We continued to use the Myers-Briggs Type Inventory ${ }^{11}$ to help participants understand their own approaches to other people and leadership dilemmas. Now, after they process and understand their own styles, we run a simulation that generates leadership behaviors that they can link to their own individual MBTI profiles.

\footnotetext{
${ }^{11}$ We have found the MBTI generates useful dialogue and introspection among our participants. Our purpose is to encourage self-awareness and provide a common vocabulary around the default approaches people use in leadership, rather than to provide the most detailed psychological profile possible.
} 
We incorporated content into the curriculum from Goleman's theory of social and emotional intelligence, with emphasis on self-awareness, self-management, empathy and motivation. $^{12}$

A key element in our work around personal mastery is helping the participants to recognize and take responsibility for the results they are getting in their own leadership behaviors. So often leaders say: "If I could just get my people to do X, the organization would be successful." Logically, they launch on a search to find out what is wrong with that person who won't comply. We challenge that default mode in a module we developed called "Find Yourself in the Results You Get." Additional modules on communication and feedback emphasize looking at the ways they contribute to getting results they don't want, understanding why they get the responses they do to their leadership choices, and working to change their own behavior rather than assuming the other person is the problem.

By explicitly defining the Institute class at the outset as a learning community where they take responsibility for their own learning, we challenge the participants to decide what that means in terms of their commitment to each other and the process, the ground rules for engagement, and the consequences of breaking the commitment. The decision to be an effective union leader requires a commitment to lifelong learning. This commitment involves self-reflection, critical self-assessment, critical thinking, learning how to learn, and fostering participants' openness to new possibilities, even if outside their own comfort zone. The curriculum provides a number of opportunities for greater

12 Daniel Goleman's work has been important to the changes implemented in the content of the curriculum: Working with Emotional Intelligence (1998) Random House; Social Intelligence (2005) Bantam. 
self-awareness, for explorations of motivation and values, and for the participants to challenge each other around their work as union leaders. This can represent a cultural shift in our slow-to-adapt unions, and promotes dynamic and adaptable leadership. ${ }^{13}$

We have streamlined the two fieldwork projects and implemented collective debriefing so the participants can share their direct experiences as they apply what they've learned to their unions. We have implemented a component of advising and coaching, both individually and in small groups, that strengthens the personal growth of the participants. We also formalized shared debriefing on each participant's own work at each seminar and introduced peer coaching between seminars to encourage participants' accountability and to provide them opportunities to express how they think the experience has changed them personally.

\section{A Critical Change to our TOC}

When the Institute first started, the founders were clear this was an effort to increase the levels of younger leaders, women, and people of color in individual unions and in the labor movement as a whole. As the discourse in U.S. society at large has moved to more open discussion of the problems of racial and gender and anti-immigrant discrimination, the labor movement has followed suit - too slowly and often grudgingly. A few unions early on used the Institute deliberately as a tool to push forward younger leaders, females and leaders of color.

\footnotetext{
${ }^{13}$ An example of these opportunities occurs in the first weeklong seminar. Participants experience a set of outdoor team challenges at the Cayuga Nature Center, followed by a structured reflection on whether and how their participation aligned with what they learned through the self-assessment process with the MBTI.
} 
In 2010, the Institute faculty decided the way we had been addressing issues of equity and inclusion was inadequate. Equity is a not an issue of tactics for pragmatic results. Equity and diversity are core issue of values and principles that will determine whether our movement fails or succeeds. We do not use diversity and equity interchangeably. Diversity is about who is in the room. Equity is about social power: who has it, who wields it, and who is targeted for disadvantage by it. While the Institute cohorts had always been diverse, with larger segments of younger participants and participants of color every year, and we consciously dealt with issues of racial injustice and immigration, gender discrimination, pay equity, etc., these always seemed to be elements among many others, or as an afterthought. The country had just elected Barack Obama as president, immigrant rights were at the forefront of public discourse, and economic and racial disparities were gaining public attention. Unions were clearly challenged in their ability to deal with an increasingly diverse workforce. This was reflected in the failure to promote and develop younger people and people of color; in the ambivalent response to attacks on immigrants from too many unions; failure to support pay equity; failure to organize in the South, etc. If the Institute was serious about transformational change for labor, we needed to do more. This led to the articulation of an additional element in our theory of change that can be characterized as:

TOC IV (2010) The workers' movement will not grow, and the labor movement will not change, without forthrightly addressing issues of discrimination based on gender, race, ethnicity, nationality, immigration status, among other dimensions. These divisions are deeply entrenched in the American workforce, and reflected in American culture, history, and the economy. They fundamentally weaken our movement. If emerging leaders can gain new awareness into these dynamics of difference and power; if they can surface and address these issues personally in a 
diverse, supportive, but challenging learning community of leaders from across the broader workers' movement; if they can carry new openness, new skills, and new frameworks back to their own organizations, they can change those organizations and strengthen the labor movement.

Starting in 2011 we devoted one of the six seminars in the curriculum entirely to a very challenging exploration of racial and gender equity and inclusion.. ${ }^{14}$ We began introducing the notion of social identities and difference, how these impact our experiences and our individual experiences, attitudes, and behaviors. We taught skills and concepts like tracking ${ }^{15}$ in the first session. We invited controversial speakers who raise challenges for the unions in the room, and the faculty has to be prepared and willing to address and work through those challenges and participants' reactions. We began aggressively recruiting and providing scholarships for leaders from non-traditional worker groups (who were uniformly young, and mostly people of color). We began recruiting more faculty of color. We changed the language of the program, for instance, from "labor movement" to "workers' movement" and "union" to "organization." We included examples, scenarios, and language in the curriculum from worker organizations rather than just from traditional unions. We moved away from an emphasis on "density"

\footnotetext{
${ }^{14}$ Our thinking was informed by important works such as Adams, et al. (2007) Teaching for Diversity and Social Justice; and Cox and Beale, Developing Competency to Manage Diversity (1997).
}

${ }^{15}$ Tracking is a skill in which the members of a group are trained to watch and describe to the group observations about the group's interactions, suspending all interpretation or judgment. Once something is "tracked", the whole group becomes aware of a dynamic, and is able to make new choices as the group proceeds. E.g., "I am tracking that when the chair asked that question of the group, all six of those who responded had spoken before, and five of the six were men..." 
(the proportion of eligible workers who were members of the union) as the key factor in strategic leverage for a union, to a broader definition of workers' power residing in the ability of unions and worker-based organizations to create alliances that tapped into the larger social movements and energy.

In the years since 2011, the correctness of these changes has been apparent. Occupy Wall Street put the issue of economic equality on the agenda. The murder of Trayvon Martin exposed the cancer of police brutality and saw the rise of the Black Lives Matter Movement, with its attention to the issues of mass incarceration and the "schools to prison pipeline." Now with the election of Donald Trump, we are facing the ugliness that has always lurked beneath the surface, not only in the backwaters of America, but too often in the mainstream labor movement.

\section{Leadership Development as a Strategy for Implementing Inclusion and Equity}

Assessment of outcomes is difficult in a program like this, as we defined success 19 years ago as "transforming unions and the labor movement." This program has definitely contributed to transforming some lives and some organizations. The movement itself is a moving target, engaged in an existential struggle against often overwhelming odds in a global economy restructuring every relationship for virtually every worker everywhere in some way.

The United Federation of Teachers (UFT) in New York City, an affiliate of the American Federation of Teachers, was led at the time of the Institute's launch by Randi Weingarten, who recognized that the predominantly white leadership of the UFT, in a city and a school system that is majority people of color, needed to change. In the first 
cohort, she nominated two African American teacher-activists, both still in their twenties.

LeRoy Barr is now chief of staff for the UFT, and Janella Hinds is a high level UFT

staffer. Hinds was also elected the Secretary-Treasurer of the New York City Central

Labor Council in 2012. Ms. Hinds reflected the contribution of the Institute to her

leadership trajectory.

The Institute exposed me to union people and leaders of other organizations I had no experience with. Beyond networking, it provided the space to have conversations which are more global.

Hearing out a thoughtful criticism of labor and listening to ideas

from leaders of the different unions and other workers'

organizations whose members have a big stake in a successful

labor movement is really about growing up as a thinker and a leader. ${ }^{16}$

Including leaders from alt-labor groups and workers' centers in the cohorts

broadened the range of experiences in the program, and challenged participants to see the labor movement as a broader workers' movement, rather than as a collection of mainstream labor institutions. This decision created significant discomfort, both with sponsors, and with participants, as some unions have struggled over including immigrant or even undocumented workers into their ranks at the same time they are losing market share to these exploited workers, most of whom are outside the protections of U.S labor law. Heated discussions over race, gender and immigration status are routine in the Institute, and including leaders from worker's centers and worker advocacy groups has challenged union participants to listen to and address the experiences and concerns of immigrants and immigrant-rights advocates. It also challenged the worker center leaders to examine some of the assumptions they held about unions and unionized workers. Both

${ }^{16}$ Quoted in Carroll (2012) 
groups found they had significant common ground they never would have discovered if not for this experience. The passage of the New York State Domestic Workers' Bill of Rights in 2010 was a project of the first cohort member from an alt-labor group, Priscilla Gonzales of the New York Domestic Workers United, and alliances with powerful unions in the state that she forged in the Institute were crucial to its success.

Native-born members of the Laborers' Union (LIUNA) are often divided on how the union should address the challenges of an increasingly immigrant workforce. LIUNA saw the Institute as a space to have their younger leaders involved in discussions that would broaden their thinking, rather than being limited by the traditions of their craft. Dave Johnson, Director of Organizing - Laborers Eastern Region Organizing Fund, who has sponsored dozens of young activist-organizers since 2002 under the leadership of LIUNA Eastern Regional Manager Ray Pocino, commented

Our union is primarily in the building trades sector. It is a very tough environment. ULI works with us to prepare our union's leaders for more consequential leadership roles. It is my job to help them learn and grow through education--otherwise I am setting up my own people for failure. And that kind of arrangement is harmful to labor. Contrast it with what our union's leaders get from Cornell's Institute. The leader of Local 55 in Newark is now Hector Fuentes. He was hired by our union when he spoke little English, and yet his ULI classmates voted him to be their class spokesman at their graduation in 2005. Byron Silva graduated from ULI about the same time. He first came to this country (from Ecuador) in 1990. He is now Business Manager of Laborer's Local 10 over in Long Island City. And what do you suppose he did last year? He sends Local 10 executive board member Ligia Gualpa who works with day laborers and workers' 
centers, to the Union Leadership Institute's current class. I would say ULI is a recipe for success. ${ }^{17}$

Roberta Reardon graduated from the program in 2005 while she was an elected officer of the New York City local of the American Federation of Television and Radio Artists (AFTRA). After graduating, she ran successfully for local president, then for national President. In 2010-11 she guided the union through a very difficult merger process and became the founding co-president of the new union (SAG-AFTRA), created from the merger of AFTRA and the Screen Actors Guild, the two most powerful performers' unions in the country. In 2015 she was appointed the Commissioner of Labor for the State of New York by Governor Andrew Cuomo. Reardon reflects,

I was a leader in a white-collar performers' union, and the Institute exposed me to other labor leaders whose experiences were totally different from my own, but who taught me what real solidarity for working people could mean. I left with the confidence to be a leader under very tough circumstances." (Reardon 2018)

Wendell Young, the President of Local 1776 United Food a Commercial Workers in Philadelphia sent his entire leadership team through the program over a period of four years. They chose as their Institute leadership fieldwork project setting up an internship program to recruit young activists from their retail positions into union staff positions. After the project was implemented, Young sent four young staff members who had been recruited out of that project to the Institute, and they are now moving up the leadership[p ranks in the union.

${ }^{17}$ Quoted in Carroll (2012) 
The Retail, Warehouse and Department Store union has used the Institute to train and season a number of their young activists of color, who have gone on to play major roles as local Presidents and in top national staff positions. Alvin Ramnarain (ULI '09) became President of his Local (1102) and is now sponsoring other young activists. 1199SEIU sent two young African American leaders to the program in 2010, Veronica Turner and Tyrek Lee, and Turner is now Executive Vice President of 1199SEIU regionally, and Lee is a leading staffer.

LeRoy Barr (ULI '03) reflects on the importance of the Institute, not only in developing new leaders for UFT, but also because of the outcomes of their participants' leadership fieldwork projects:

We have strong experiences with ULI graduates. They take root in our union. Our president, Mike Mulgrew, graduated from ULI a few years after me-I graduated in 2003 - and that was before he became our union's elected leader. A different example is the UFT's bullying project, a major focus. It's changing our union by deepening our relationship with students and parents. It was started as a fieldwork project last year by our health and safety director when he was a student in the ULI. 18

The process is not always smooth. In several instances, Institute participation has promoted the rise of young leaders (many of color and women) who then challenge their sponsors for leadership positions. After graduation, Wayne Spence ran successfully against his sponsor for president of his statewide public-sector union, Public Employees Federation (PEF), and is now sending top leaders through the program. New York State

${ }^{18}$ Quoted in Carroll (2012) 
United Teachers (NYSUT) elected an entire new executive Board in 2015 consisting mainly of Institute graduates who had challenged their leadership. Obviously, we cannot control the future decisions of graduates, but these relationships can be very complicated. The Leadership Institute and the Worker Institute at ILR has a strict policy of noninterference in any union's internal affairs, including (especially) around elections.

Tracking the demographics of the cohorts over time indicates the Institute has been successful in increasing the number of women, people of color and younger leaders who are being sponsored by their organizations. The diversity of the first class was unique in 2003, and the percentages have gone up over time (See Appendix A). The most recent cohorts (2017-18) have been $61 \%$ of color, $78 \%$ under the age of 45 , and $51 \%$ female. This change in Institute demographics may also partly reflect the changing discourse within and without the labor movement around equity and inclusion, and by the increasing number of immigrant workers who are seeking representation either from mainstream unions, or from organizations of their own making.

Anecdotal evidence about the leadership trajectory of many of our graduates is highly promising. We have seen organizations putting younger leaders in place after sending them to the Institute. Some of New York's largest and most influential unions have developed a sense of ownership and commitment to the Institute as their own and use the Institute as a way to expose promising young activists to the larger movement and to a process of personal support as well as personal transformation.

Janella Hinds (ULI '03) has stayed involved as a sponsor and close advisor throughout the evolution of the program:

The perspectives ULI provides helped me to see clearly that labor leaders need to challenge traditions of thinking and transform 
them, while at the same time reminding us of our motivating values, labor values. This is the solid ground transformational leadership leads us to in the Institute. It is a tool for labor leaders to escape the limits of entrenched thinking, both in how their unions function and in how they view themselves. ${ }^{19}$

The Institute benefits from the ongoing support of the NYS AFL-CIO and from the guidance of an active Executive Committee of participating unions and alumni. Several large unions are using the Institute as the next step for talented younger leaders after they complete their own internal union training. We are constantly evaluating and revising, trying new things, struggling with limited resources and high need.

Without courageous and visionary leaders, we face a very uncertain future: one without protections, without vehicles for collective voice, and without democracy. Hopefully, the ideas and experiences here can be useful in the growing dialogue among those convinced that leadership development is a critical need with tremendous potential for helping the labor movement grow in size and effectiveness.

${ }^{19}$ Quoted in Carroll (2012) 


\section{Works Cited.}

Adams, Maurianne, Lee Anne Bell, Pat Griffin. (2007) Teaching for Diversity and Social Justice. Routledge. New York.

Alvarez, S.M., Whitefield, Pam, Emrani, Yasmin. (2009) "Is there a Woman's Way of Organizing? Gender, Unions, and Effective Organizing." ILR Research Studies and Reports. Available at http://digitalcommons.ilr.cornell.edu/reports/26/

Carroll, Eugene. (2012). “Developing Labor Leadership: Assessing a Journey to Solid Ground" Capstone project for Master's degree in Labor Studies. City University of New York. Available from the author.Gc32@cornell.edu

Clark, Paul. (2009) Building More Effective Unions. second edition. ILR Press. Cornell University. Ithaca,

Barling, Julian, Kelloway, E. Kevin, and Fullagar, Clive. (1992). The Union and Its Members: A Psychological Approach. Oxford University Press. New York.

Barling, Julian, Kelloway, E. Kevin, and Fullagar, Clive. (1995). "The Role of Transformational Leadership in Shop Steward Effectiveness." Workplace Topics, 23-26. Washington D.C.: AFL-CIO Department of Economic Research (December).

Clark, Paul F. (2000). "Behavioral Science and Union Effectiveness.” Building More Effective Unions. Ithaca: Cornell University Press.

Cox, Taylor and Ruby L. Beale. (1997). Developing Competency to Manage Diversity. Berrett-Koehler. San Francisco.

Eisenscher, Michael. (1999). "Leadership Development and Organizing: For What Kind of Union?” Labor Studies Journal, 3-21, (Summer). 
Fontes, Marlena and Ken Margolies (2010). "Youth and Unions." Research report produced by the Worker Institute at Cornell ILR. Available at http://digitalcommons.ilr.cornell.edu/cgi/viewcontent.cgi?article=1103\&context=working papers

Freire, Paulo (1970). "The Banking Model of Education". In Provenzo, Eugene F. Critical Issues In Education: An Anthology of Readings. Thousand Oaks, CA: Sage Publications. pp. 105-117.

Gomez, Rafael, Morley Gunderson, Noah Meltz. (2002). "Comparing Youth and Adult Desire for Unionization in Canada.” British Journal of Industrial Relations. 40: 3 September, 0007-1080, pp.521-542.

Hammer, Tove and David Wazeter. (1993). "Dimensions of Local Union Effectiveness," ILR Review. Volume 46:2, 302-319. available at http://journals.sagepub.com/doi/abs/10.1177/001979399304600206

Kolb, Alice Y. and David A. Kolb. (2005). "Learning Styles and Learning Spaces: Enhancing Experiential Learning in Higher Education.” Academy of Management Training \& Education, Volume 4, No. 9, p. 193-212.

Muste, A.J. (1928). "Factional Fights in Trade Unions: A View of Human Relations in the Labor Movement," in American Labor Dynamics in the Light of Post-War Developments, ed. J. B. S. Hardman. Harcourt, Brace and Company. New York.

Needleman, Ruth. (1993). "Space and Opportunities: Developing New Leaders to Meet Labor's Future." Labor Research Review. Volume 1, Number 20.

Reardon, Roberta. (2018). Interview. New York City. January 6. 
Timm, Jonathan. (2015). “Can Millennials Save Unions?” The Atlantic. September 7. Available at https://www.theatlantic.com/business/archive/2015/09/millennialsunions/401918/

Weil, David. (2005). "A Strategic Choice Framework for Union Decision Making." WorkingUSA: The Journal of Labor and Society, March, Volume 8, pp. 327-347. 